Niceliksel Çalışma

\title{
Sürücü Davranışlarının Kişiler Arası Döngüsel Model Üzerindeki Temsilleri
}

\author{
Uzm. Psk. Özge Özer \\ Dr. Öğr. Üyesi Bahar Öz \\ Orta Doğu Teknik Üniversitesi \\ Fen-Edebiyat Fakültesi, Psikoloji Bölümü
}

\begin{abstract}
$\ddot{O} \mathbf{z}$
Bu çalışmanın amacı, sürücü davranışlarının kişiler arası döngüsel model (KDM) üzerindeki konumlarını kişiler arası problemler temelinde saptamaktır. Sürücü davranışlarının pek çok farklı faktörle ilişkisini araştıran birçok çalışma olmasına rağmen, bu davranışlar doğrudan kişiler arası problemlerle ilişkilendirilerek incelenmemiştir. Çalışmaya toplam 355 sürücü (109 kadın, 246 erkek) katılmıştır ve katılımcılardan Sürücü Davranışları Ölçeği, Pozitif Sürücü Davranışları Ölçeği ve Kişiler Arası Problemler Envanterini doldurmaları istenmiş̧tir. Çalışma değişkenleri arasındaki ilişkiyi incelemek amacıyla sürücü davranışlarının KDM üzerindeki konumları incelenmiştir. KDM'de sürücü davranışlarının konumlarını saptamak için ipsatize veri yöntemi kullanılmıştır. Sonuçlar, sürücü davranışları ve kişiler arası problemler arasındaki ilişkilerin KDM üzerindeki konumlandırılmasının bu iki değişkenin alt ölçeklerinin özelliklerine uygun bir şekilde gözlemlendiğini göstermektedir. Kişiler arası problemlerin ve sapkın/pozitif sürücü davranışları arasındaki ilişkinin açıklanması, trafik bağlamında kişilik ve kişiler arası ilişkileri araştıran literatüre katkı sağlamaktadır.
\end{abstract}

Anahtar Kelimeler: Sürücü davranışları, kişiler arası problemler, kişiler arası döngüsel model 


\title{
Representations of Driver Behaviors on the Interpersonal Circumplex Model
}

\author{
Özge Özer, M. A. \\ Bahar Öz, Asst. Prof. \\ Middle East Technical University \\ Faculty of Arts \& Sciences, Department of Psychology
}

\begin{abstract}
The aim of the current study was to investigate the relationship between driver behaviors and interpersonal behaviors and detecting the positions of driver behaviors on interpersonal circumplex (IPC). Although there were many studies that explore the associations of driver behaviors with many different individual factors, driver behaviors are not studied directly with interpersonal problems. A total of 355 drivers (109 females, 246 males) participated in this study and they were given The Driver Behavior Questionnaire with the Positive Driver Behaviors Scale and Inventory of Interpersonal Problems for measuring the variables of the study. Ipsatized data method was used for detecting the positions of drivers in the IPC. Results showed that, the characteristics of the relationship between driver behaviors and interpersonal problems are in accordance with the representations of the driver behaviors on the IPC. Evidencing the interpersonal problems and aberrant / positive driver behaviors relationship was a theoretical contribution to the literature investigating personality and interpersonal relationships at traffic context.
\end{abstract}

Keywords: Driver behaviors, interpersonal problems, interpersonal circumplex 


\section{Sürücü Davranışlarının Kişiler Arası Döngüsel Model Üzerindeki Temsilleri}

\section{Giriş}

Trafik kazaları dünyadaki en büyük ölüm ve yaralanma nedenlerinden biridir. Dünya Sağlık Örgütü'nün (WHO, 2015) raporuna göre, trafik kazalarında yıllık 1,25 milyon kişi ölmekte ve 20 ila 50 milyon arasında kişi yaralanmaktadır. Trafik insan hayatının büyük bir parçasıdır ve trafik ortamı insanlar için tehlike oluşturabilse de aynı zamanda sosyal bir ortamdır. Bu sosyal ortamda insanlar sosyal varlıklar olduklarını yansıtan davranışlar sergiler ve karmaşık kişiler arası ilişkilere dâhil olurlar. İnsanların yaşamlarını sürdürmeleri için birbirleriyle işbirliği yapmaları oldukça önemlidir; karşılaştıkları sıkıntının önemli bir kısmı da kişiler arası ilişkilerde bu işbirlikleri sırasında yaşadıkları problemlerden kaynaklanmaktadır (Çabuk, 2015). İnsanların doğaları gereği diğer insanlarla aktif olarak etkileşime girdikleri ortamlardan biri de trafik ortamıdır. Bu ortamda bütün sürücüler diğer yol kullanıcıları ile (örneğin, sürücüler, yolcular, yayalar) aktif etkileşim içinde varlık gösterirler. Her ortamda olduğu gibi, insanların trafik ortamlarında etkileşime girerken karşılaştıkları problemler de bu ortamlardaki tutum, karar ve davranışlarına yansımaktadır.

\section{Sürücü Davranışları}

İnsanlar trafik ortamında sürücü, yaya, bisikletli ve yolcu gibi çeşitli roller almaktadırlar.

Her bir rolün trafik güvenliğine farklı etkisi bulunmakla birlikte, yapılan araştırmalar incelendiğinde trafik kazalarının çoğunun sürücülerin davranışlarından kaynaklandığı görülmektedir (EGM, 2017). Dolayısıyla, sürücü davranışlarının trafik ortamlarındaki önemli rolü ve etkisi yadsınamazdır. Sürücü davranışları iki temel boyut altında incelenen "sürücülükte insan faktörleri"nin bir boyutunu temsil etmektedir, diğer boyut ise sürücü becerileridir. Elander, West ve French'e (1993) göre, sürücü davranışları, sürücülerin (alışkanlık olarak) araç sürmeyi seçme yolları olarak tanımlanabilmektedir. Başka bir deyişle, sürücülerin trafik ortamında genellikle neler "yaptıkları" anlamına gelmektedir. Öte yandan, sürücü becerileri alg1-motor ve güvenlik becerilerinden oluşmaktadır ve sürücülük deneyimi ile artmaktadır (Elander ve ark., 1993). Başka bir deyişle, trafik ortamında sürücülerin neler "yapabildikleri" anlamına gelmektedir. Bu çalışma kişilerarası etkileşimin davranış ile ilişkisine odaklandığı için bahsedilen iki tip sürücülükte insan faktöründen sürücü davranışlarını incelemeyi hedeflemiştir. $\mathrm{Bu}$ nedenle takip eden kısımlarda sürücü davranışlarına ayrıntılı olarak değinilmektedir.

Reason (1990)'a göre sürücü davranışları genel olarak iki temel boyut altında incelenebilir: hatalar ve ihlaller. Reason, Manstead, Stradling, Baxter ve Campbell'in (1990) bu ayrımı temel alarak yürüttükleri çalışmalar ve trafikte sapkın (kuraldan sapan) davranışları ölçmek için geliştirdikleri Sürücü Davranışları Ölçeği (SDÖ), sürücü davranışları araştırmalarında kilometre taşı olarak görülmektedir. Reason ve arkadaşlarının (1990) istemli ihlaller, istemsiz ihlaller, yanlışlıklar, ihmal ve dalgınlıklardan oluşan beş faktörlü bir sapkın sürücü davranışı modeli elde etmeyi amaçlayan çalışmalarında, sonuçlar istemli ihlaller, tehlikeli hatalar ve gülünç hatalardan oluşan üç faktörlü bir yap1 ortaya çıkarmıştır. İhlaller "potansiyel olarak tehlikeli bir sistemin güvenli bir şekilde yürütülmesi için gerekli olduğuna inanılan uygulamalardan kasıtlı sapmalar (örneğin, Kırmızı 1ş1kta geçmek)" olarak tanımlanmaktayken; hatalar "planlanan eylemlerin 
amaçlanan sonuçlarına ulaşmada plan veya niyet yetersizliği sebepleriyle başarısızlık yaşanmasıdır (örneğin, Sollama yaparken karşıdan gelen aracın hızını yanlış hesaplamak)”. İhmal ve dalgınlıklar ise "yeterli planın hafıza veya dikkat sorunları sebebiyle uygun şekilde tamamlanamaması durumunda ortaya çıkan davranış tipleridir (örneğin, farları yakmaya niyetlenmişken silecekleri çalıştırmak)". Farklı çalışmalarda da kanıtlanan, temelde hata-ihlal ayrımına dayanan bu üçlü faktör yapısı daha sonra Lawton, Parker, Manstead ve Stradling (1997) tarafından ihlallerin siradan ihlaller ve saldırgan ihlaller olarak ayrıştırılmasıyla dörtlü bir yapıya dönüşmüştür: saldırgan ihlaller, sıradan ihlaller, hatalar, ihmal ve dalgınlıklar. Sıradan ihlaller "güvenli sürücülükten belirgin bir saldırgan amaç olmaksızın niyetli bir şekilde çıkmak (örneğin, zaman kazanmak için aşırı hızlı araç kullanmak)" şeklinde tanımlanırken; saldırgan ihlaller "açık bir şekilde saldırgan niyetler içeren sürücü davranışları (örneğin, trafikte ilerlerken diğer araçları sıkıştırmak yoluyla saldırganlık göstermek)" şeklinde tanımlanmaktadır. Dünya çapında günümüze kadar pek çok çalışmada kullanılmış olan SDÖ farklı çalışmalarda farklı faktör yapıları göstermiş olsa da; sonuç olarak hata ve ihlalden oluşan iki temel faktörlü yapısının farklı kültür ve sürücü gruplarında geçerli olduğu görülmektedir (Bkz. Wallén Warner, 2006; Özkan et al., 2006a). Lajunen, Sümer ve Özkan (2003) SDÖ’yü Türkçeye uyarlamış, Türkiye örnekleminde de SDÖ'nün hata ve ihlallerden oluşan iki temel faktörlü yapısını desteklendiği bulunmuştur. Buna göre, hatalar boyutunun ihmal ve dalgınlıkları; ihlallerin de sıradan ihlaller ve saldırgan ihlaller boyutlarını içerdiği belirtilmiştir.

Hatalar ve ihlaller trafikteki sapkın davranışların temel boyutlarını temsil ederken, trafikte gündelik sürücülükte sapkın davranışlardan başka davranışlar da bulunmaktadır (Özkan \& Lajunen, 2005). Bu davranışlar kurallara ve yönetmeliklere bağlı olmak veya güvenliği göz önüne almak gibi zorunlulukları olmayan davranışlardır (örneğin, Sollamayı kolaylaştırmak için yolun să̆ tarafına çekilmek). Bu davranışların en önemli motivasyonu, trafik ortamı için veya diğer yol kullanıcıları için dikkatli olmak, güvenlik endişeleri olmadan da yardım etmek ve kibar olmaktır. Bu tür davranışlar Özkan ve Lajunen (2005) tarafından "Pozitif Sürücü Davranışları" olarak adlandırılmış ve ölçümleri için aynı isimli bir ölçüm aracı geliştirilmiştir. Tanım ve içeriklerine bakıldığında pozitif sürücü davranışlarının trafik ortamında kişiler arası etkileşim ile ilişkisi dikkat çekmektedir.

\section{Kişiler Arası İlişkiler ve Döngüsel Model}

Daha önce vurgulandığı gibi, insanlar sosyal varlıklardır ve tüm davranışları, bireysel değişkenlere ek olarak sosyal ilişkilerinden de etkilenir. Kişiler arası ilişkilerinde insanlar çeşitli tutum, inanç, sorun ve davranışlar sergilerler. Foa'nın (1961) belirttiği gibi, kişiler arası davranışlar hem bir kişinin kendine ve diğerlerine karşı duygusal bir ilişki kurma girişimidir hem de kendiyle ve daha büyük bir grupla bir bağ kurma girişiminde bulunmasıdır. Horowitz ve arkadaşları (2006), kişiler arası davranışları motivasyonlu davranışlar olarak tanımlamaktadır.

Örneğin, bir kişi başka biriyle etkileşim içinde olmaya başladığında, bu davranışın hedefe yönelik olduğu varsayılır. Bununla birlikte, kişinin bu amaç hakkında bilinçli olması her zaman gerekli değildir ve bu hedefin önem derecesi "önemsiz"den "hayati derecede önemli"ye kadar farkl1lık gösterebilmektedir (Horowitz ve ark., 2006). Tüm bunların yanı sıra duygusal yakınlığın da insanların kişiler arası davranışlarını planlama ve yürütme yöntemleri ve içeriği üzerinde büyük ve karmaşık bir etkisi olduğu vurgulanmıştır (Forgas, 2002). Davranış ve duygusal yakınlık dışında, 
kişiler arası davranışlar insanlar arasındaki beklentilerden de etkilenir; sosyal uyum için kişiler arası beklentiler gereklidir (Jones, 1986). Kişiler arası davranışlar farklı tiplere sahiptir ve özel modeller kapsamında incelenirler; döngüsel model bu davranışları inceleyen yöntemlerden biridir.

Bireylerin kişiler arası davranışlarının sınıflandırılması ampirik olarak üretilen bir dairesel model oluşturmaktadır (Pincus ve Ansell, 2003). Bu dairesel alana "circumplex (döngüsel model)" adı verilir; döngüsel model iki boyuttan oluşur (Bkz. Şekil 1). Horowitz ve ark (2006), bu boyutlardan sırasıyla "insanlar arasındaki bağlantı" ve "bir kişinin diğerine olan etkisi”" olarak bahsetmişlerdir. Bu modele göre, "yakınlık" ve "baskınlık" bir döngü üzerindeki temel koordinatları temsil eder; dolayısıyla, kişiler arası davranış bu koordinatların bir kombinasyonu olarak açıklanabilir (Alden ve ark., 1990; Horowitz ve ark., 2003; Akyunus ve Gençöz, 2016).

Yatay eksende yakınlık boyutu, düşmanca davranışlar ve arkadaşça davranışlar uçları arasında değerlendirilebilirken; dikey eksendeki baskınlık boyutu hakimiyet ve teslim olma uçları arasında incelenmektedir (Bkz. Alden ve ark., 1990; Horowitz ve ark., 2003; Akyunus ve Gençöz, 2016). Döngünün iki ana boyutunun harmanlanması, döngüsel alandaki tüm bireysel farkl1lık özelliklerini tanımlayabilir. Modelde "oktant" olarak bahsedilen bu ayrımlar döngünün $360^{\circ}$ çevresinde içeriklerine göre aldıkları isimlerle sıralanmaktadır (Bkz. Şekil 1). Döngüde birbirine komşu olan oktantlar kavramsal ve istatistiksel olarak benzerdir, $90^{\circ}$ deki oktantlar kavramsal ve istatistiksel olarak bağımsızdır ve $180^{\circ}$ 'deki oktantlar kavramsal ve istatistiksel olarak karşıtlardır (Pincus ve Ansell, 2003). Örneğin ‘baskın’ ve 'arkadaşça-baskın’ oktantları komşu oldukları için birbirlerine benzer, 'itaatkâr' ve 'arkadaşça' oktantları $90^{\circ}$ 'de konumlandıkları için birbirlerinden bağımsız ve 'dominant' ve 'itaatkâr' oktantları $180^{\circ}$ 'de konumlandıkları için karşıtlardır. Döngüsel modelin bir başı ya da bir sonu yoktur ve bir süreklilik içerir (Gurtman ve Pincus, 2000; Pincus ve Ansell, 2003). KDM bileşenlerinin birbirleri ile herhangi bir etkileşimi bulunmamaktadır (Pincus ve Ansell, 2003). Bireylerin yaşadığı kişiler arası işlevsellikteki çeşitli zorlukları ölçmek için, kişiler arası döngüsel model (KDM) temel alınarak, Kişilerarası Problemler Envanteri (KPE) adlı envanter geliştirilmiştir (Horowitz, Rosenberg, Baer, Ureno ve Villasenor, 1988). KDM'nin sekiz oktantıyla bağlantılı olarak, KPE sekiz alt ölçek içerir. Bununla birlikte, KPE alt ölçeklerinde oktantların isimleri değiştirilmiştir; diğer bir deyişle KPE alt ölçeklerinin isimleri KDM'deki oktant isimleriyle aynı değildir. Ancak, KPE alt ölçek içerikleri KDM'deki oktantların içeriklerine göre geliştirilmiştir. KDM oktantlarının, KPE alt ölçeklerinde adlandırılması sırası ile şu şekildedir: 'baskın' oktantı 'dominant/kontrolcü' alt ölçeği; 'düşmanca-baskın' oktantı 'kinci/benmerkezci' alt ölçeği; 'düşmanca' oktantı 'soğuk/mesafeli' alt ölçeği; 'düşmanca- itaatkâr' oktantı 'sosyal çekinik' alt ölçeği; 'itaatkar' oktant1 'kendine güvenmeme/girişken olmama' alt ölçeği; 'arkadaşça-itaatkar' oktantı 'aşırı uyumluluk' alt ölçeği; 'arkadaşça' oktantı 'kendini feda etme' alt ölçeği; son olarak da 'arkadaşça-baskın' oktantı 'sırnaşıklık/muhtaçlık' alt ölçeği.

KPE alt ölçeklerinin/oktantlarının isimlendirilmeleri olumlu da olsa olumsuz da olsa problemli bir durumu yansıtır. Örneğin, düşmanca-baskın oktantında yer almak bu özelliklere problemli bir şekilde sahip olmayı gösterir. Aynı şekilde arkadaşça-itaatkâr oktantında yer almak da bu özelliklere fazla seviyede sahip olma problemli durumunu belirtir. 


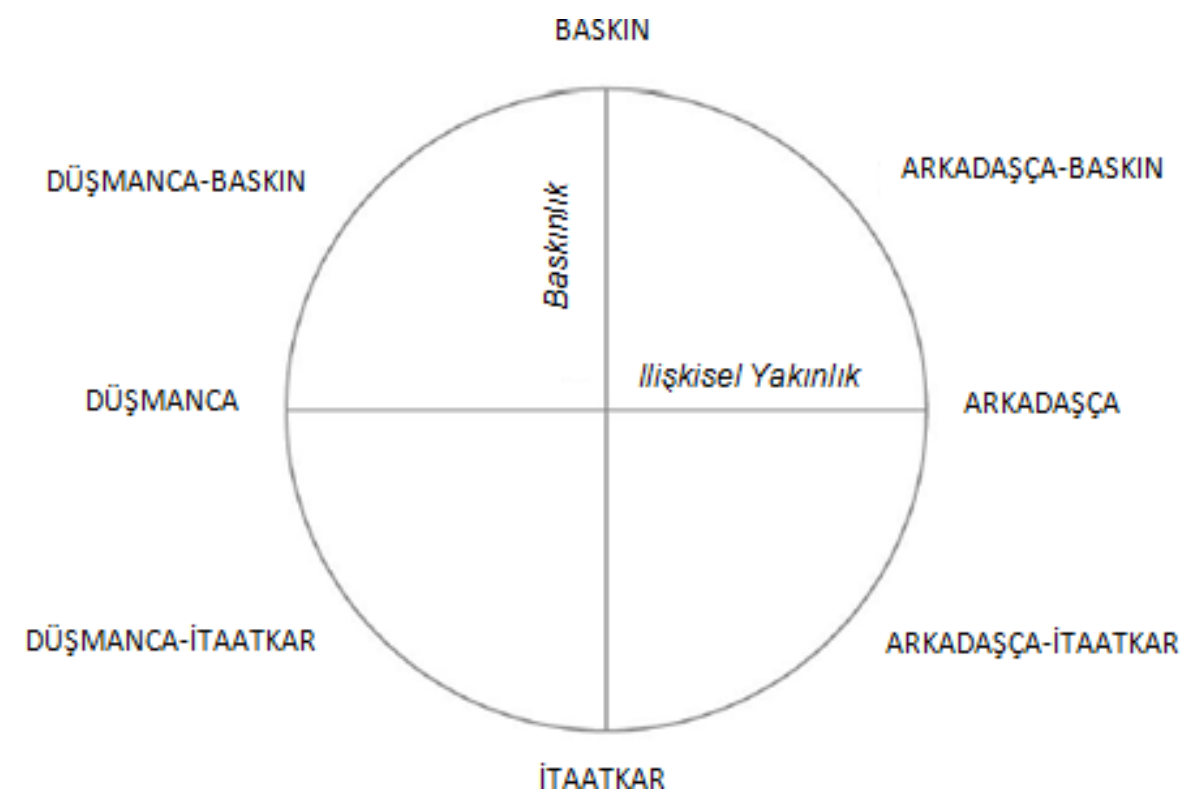

Şekil 1. Kişiler Arası Döngüsel Model (Akyunus ve Gençöz, 2016)

\section{Çalışmanın Amacı}

Kişilerarası ilişkilerdeki zorlukların farklı davranışlara yansıması alan yazında çalışılmış bir konudur. Önceki çalışmalara bakıldığında insanların patolojik ilişki ve iletişimlerinin incelendiği klinik alanda, kişiler arası problemlerin çalışılan bir değişken olduğu görülmektedir. Örneğin, kişilik bozuklukları (Alden ve Capreol, 1993; Stern, Kim, Trull, Scarpa ve Pilkonis, 2000; Lejuez ve ark., 2003) ve klinik terapötik kullanımlar (Muran, Segal, Samstag ve Crawford, 1994; Borkovec, Newman, Pincus ve Lytle, 2002; Hansen ve Lambert, 1996) kişiler arası problemler ile ilişkilendirilmiş değişkenlerdir. Bununla birlikte, sürücü davranışları bu değişkenlerden biri değildir. Birçok özellik ve problemli durumla ilişkisi çalışılmış olan kişiler arası problemlerin incelenmesi trafik ortamlarında sergilenen davranışları anlamlandırmak için ek ve anlamlı veri sağlayacaktır. Sürücüler, trafikle ilgili uyaranlardan olumsuz veya olumlu olarak etkilenebildikleri gibi, duygularını, streslerini veya günlük yaşantılarındaki kaygılarını da trafik ortamına aktarmaktadırlar. Trafik ortamı, kişiler arası etkileşimi içeren bir ortamdır. Sürücüler trafikte yalnız değildir, ifadeleri ve tutumları yollardaki davranışlarına yansır ve trafik ortamındaki pozitif ve negatif etkileşimler ve davranışlar yoluyla sürücüler arası iletişim sağlanır. Kişilerin kişiler arası ilişkilerde sahip oldukları sorunlar, davranışları aracılığıyla kendilerini ifade etme biçimlerine yansır. Bu durum her ortamda olduğu gibi trafik ortamlarında da geçerlidir; ancak bugüne kadar herhangi bir model temelinde incelenmemiş bir durumdur. Bu çalışmanın amacı kişiler arası döngüsel model üzerinde farklı sürücü davranışlarının temsillerini incelemek, bu yolla sürücülerin kişiler arası ilişkilerdeki problemlerinin trafikteki sapkın ve pozitif davranışlarla nasıl ilişkilendiğini incelemektir.

\section{Katılımcılar}

\section{Yöntem}


Araştırmanın örneklemi, ehliyet sahibi ve düzenli olarak araç kullanan, yaşları 18-70 arasında değişen $\left(\mathrm{M}_{\text {yaş }}=36.46\right) 355$ (109 kadın, 246 erkek) kişiden oluşmaktadır. Çalışmaya Türkiye'nin farklı şehirlerinde yaşayan sürücüler katılmıştır (katılımcılarla ilgili ayrıntılı bilgiler için bkz. Tablo 1 ve Tablo 2).

Tablo 1. Katılımcıların tanımlayıcı özellikleri.

\begin{tabular}{|c|c|c|c|c|c|}
\hline & $\mathrm{N}$ & Min & Maks & Ort & $\begin{array}{c}\text { Standart } \\
\text { Sapma }\end{array}$ \\
\hline Yaş & 355 & 18 & 70 & 36.46 & 13.38 \\
\hline $\begin{array}{l}\text { Geçerli ehliyet sahibi } \\
\text { olunan süre (yıl } \\
\text { olarak) }\end{array}$ & 355 & 1 & 47 & 14.64 & 11.02 \\
\hline $\begin{array}{l}\text { Yillk yapilan mesafe } \\
\text { (Km olarak) }\end{array}$ & 323 & 200 & 150000 & 14059.60 & 18004.73 \\
\hline Aktifkaza sayısı & 352 & 0 & 5 & .80 & 1.08 \\
\hline Pasifkaza say 151 & 352 & 0 & 5 & .51 & .98 \\
\hline
\end{tabular}

Tablo 2. Katılımclların ĕgitim seviyeleri.

\begin{tabular}{lccc}
\hline \multicolumn{1}{c}{ Eğitim seviyesi } & Frekans & Yüzde & Toplam yüzde \\
\hline İlkokul & 2 & .6 & .6 \\
Ortaokul & 6 & 1.7 & 2.3 \\
Lise & 38 & 10.6 & 13.0 \\
Yüksekokul & 47 & 13.2 & 26.2 \\
Üniversite & 210 & 58.8 & 85.4 \\
Yüksek Lisans- & 52 & 14.6 & 100.0 \\
Doktora & 355 & 99.4 & 100.0 \\
Toplam & & & \\
\hline
\end{tabular}

\section{Yöntem}

Çalışma verisi toplanmadan önce, ODTÜ İnsan Araştırmaları Etik Kurulu'ndan etik onay alınmıştır. Daha sonra, katılımcılar çalışmaya e-posta ve sosyal medya duyuruları yoluyla davet edilmiştir. Çalışma başladığında, katılımcılara bilgilendirilmiş bir onay formu verilmiştir. Bazı katılımcılar çalışmayı Qualtrics (Qualtrics, Provo, UT) programı üzerinden çevrimiçi tamamlamıştır, çevrimiçi sistem yoluyla çalışmaya katılımı mümkün olmayan diğer katılımcılara çalışma ölçekleri basılı olarak sunulmuş ve çalışmaya katılımları sağlanmıştır. Katılımcılara kimlik bilgileri içeren herhangi bir soru yöneltilmemiş ve araştırma sonuçlarının gizliliği ile ilgili bilgi verilmiştir. Bu adımlar tamamlandığında katılımcılardan demografik bilgi formu ve araştırma ölçeklerinden oluşan anketi tamamlamaları istenmiştir.

\section{Materyaller}

\section{Demografik Bilgi Formu}

Katılımcılara yaşları, cinsiyetleri, eğitim düzeyleri, ehliyet sahibi olma süreleri (yıl olarak), son bir sene içerisinde kaç kilometre yol kat ettikleri, aldıkları trafik cezaları ve son 3 yıl içinde 
karıştıkları kaza sayısı sorulmuştur.

\section{Kişilerarası Problemler Envanteri - Döngüsel Model (KPE-D)}

KPE-D (Horowitz, Rosenberg, Baer, Ureno ve Villasenor, 1988), kişilerin kişiler arası ilişkilerindeki zorlayıcı deneyimleri açıklamak için geliştirilmiş, katılımcıların bu konudaki tutumlarını ölçen 5 puanlı Likert tipi bir ölçektir (1 = Hiç değil, 5 = Fazlasılla). Sekiz alt ölçek içeren (Dominant/Kontrolcü, Kinci/Benmerkezci, Soğuk/Mesafeli, Sosyal Çekinik, Kendine güvenmeme/Girişken olmama, Aşırı Uyumluluk, Kendini Feda Etme, Sırnaşıklık/Muhtaçlık) 32 maddelik bir öz bildirim ölçeğidir ve tüm alt ölçekler dörder maddeden oluşmaktadır.. KPE-D’nin Türkçe uyarlaması Akyunus ve Gençöz (2016) tarafından yapılmıştır. Çalışmada kullanılan ölçeğin Cronbach alfa iç tutarlılık katsayısı katsayısı .87 olmakla beraber alt ölçeklerin güvenilirlik skorları ise Dominant/Kontrolcü için .65, Kinci/Benmerkezci için .70, Soğuk/Mesafeli için .70, Sosyal Çekinik için .80, Kendine güvenmeme/Girişken olmama için .63, Aşırı Uyumluluk için .56, Kendini Feda Etme için .74, Sırnaşıklık/Muhtaçlık için .08'dir.

\section{Sürücü Davranışları Ölçeği (SDÖ)}

SDÖ (Lawton ve ark., 1997) katılımcıların sapkın sürücü davranışlarının sıklıklarını derecelendirdikleri 6 puanlı Likert tipi bir özbildirim ölçeğidir ( 1 = Hiçbir zaman, $6=$ Her zaman). Dört alt ölçekten oluşan ve toplamda 28 maddesi bulunan SDÖ’nün ihmal ve dalgınlıklar alt ölçeğinde 8 madde, hatalar alt ölçeğinde 8 madde, saldırgan ihlaller alt ölçeğinde 3 madde ve sıradan ihlaller alt ölçeğinde 9 madde bulunmaktadır. Bu çalışma kapsamında SDÖ’nün hatalar, sıradan ihllaler, saldırgan ihllaler ve ihmal ve dalgınlıklar alt ölçeklerinin Cronbach alfa iç tutarlılık katsayıları sırasıyla $.47, .76, .65$ ve .57 'dir. Çalışmanın genel iç tutarlılık katsayısı ise .76 'dir.

\section{Pozitif Sürücü Davranışları Ölçeği (PDÖ)}

Çalışmada pozitif sürücü davranışlarını ölçmek için kullanılan Pozitif Sürücü Davranışları Ölçeği (Özkan ve Lajunen, 2005 - PDÖ) davranış sıklığı derecelendirmesinin (1 = Hiçbir zaman, 6 = Her zaman) yapıldığı 6 puanlı Likert tipi bir özbildirim ölçeğidir ve 9 maddeden oluşmaktadır. Bu çalışma kapsamında PDÖ’nün Cronbach alfa iç tutarlılık katsayısı .80 olarak bulunmuştur.

\section{Bulgular Analiz Yöntemi ve Alt Ölçek Oluşturma}

Bu çalışmada, tüm analizler "IBM SPSS Statistics V.20" programı ile yapılmıştır. İlk aşamada, KPE-D’nin dominant, kinci, soğuk, sosyal çekinik, kendine güvenmeme, aşırı uyumluluk, kendini feda etme, muhtaçlık alt ölçekleri/oktantları ortalamaları alınarak hesaplanmıştır. SDÖ’nün hata, saldırgan ihlal, sıradan ihlal, ihmal ve dalgınlıklar faktörlerinin ve pozitif sürücü davranışları ölçeğinin alt ölçekleri ortalama alınarak oluşturulmuştur. Sonraki aşamada bu alt ölçekler kullanılarak analizler yapılmıştır. Daha sonraki aşamada sürücü davranışlarının kişiler arası döngüsel model üzerinde temsil edilişini görebilmek için SDÖ, PDÖ ve KPE-D ile önceki çalışmalara göre benzer istatistiksel prosedürler uygulanmıştır (Locke, 2010; Akyunus ve Gençöz, 2016). Bu prosedürlere göre ilk adım ham datayı göreli puanlar datasına (ipsatized data) dönüştürmektir. Bu işlemdeki amaç, kişiler arası döngüsel modelin iki uçlu iki 
temel boyuttan oluşan yapısının ortaya çıkarılmasıdır (Alden ve ark., 1990). Göreli puanlar datasının elde edilmesi için her bireyin tüm ölçek ortalaması o bireyin her bir madde puanından çıkarılması gerekmektedir. Daha sonra, her bireyin baskınlık ve yakınlık boyutları üzerindeki konumunun belirlenmesi için, Locke'un (2010) formülü ile baskınlık ve yakınlık boyutlarının her iki yönde uzanan vektörlerinin puanları belirlenmiş ve aynı boyuttaki vektörlerin puanları birbirinden çıkarılmıştır. Vektör puanlarının hesaplanmasında alt ölçeklerin ortalama puanları kullanılmıştır. Vektör puanlarının hesaplamalarına ilişkin formül (Locke, 2010) aşağıdaki örneklenmiştir:

Baskın Vektörü: (0.414)(Baskınlık + (=.707).(Düşmancıl Baskın + Yakın Baskın) İtaatkâr

Vektörü: (0.414)(İtaatkâr + (=.707).(Soğuk İtaatkâr + Yakın İtaatkâr)

Sonuç olarak, bireyin Y ekseni üzerindeki konumunu (puanını) belirlemek için baskın ve itaatkâr vektörlerinin farkı, bireyin X ekseni üzerindeki konumunu (puanını) belirlemek için ise soğuk-düşmancıl ve yakın-arkadaşça vektörlerinin farkı hesaplanmıştır (Locke, 2010). Son adımda ise, sürücü davranışları ölçek puanları ile kişiler arası döngüsel model ölçeklerin $\mathrm{X}$ ve Y ekseni puanlarının korelasyonu alınarak (Wiggins ve Pincus, 1989) sürücü davranışlarının X ve Y koordinatları belirlenmiş ve kişiler arası döngüsel model üzerindeki konumları belirlenmiştir (Akyunus ve Gençöz, 2016).

\section{Döngüsel Model Üzerinde Sürücü Davranışlarının Kişiler Arası Problemler Temelinde İncelenmesi}

Sonuçlar değerlendirildiğinde, katılımcıların pozitif sürücü davranışları öz bildirim sıklıklarının, sapkın sürücü davranışları (hata, sıradan ihlal ve saldırgan ihlal, ihmal ve dalgınlıklar) öz bildirim sıklıklarından daha fazla olduğu görülmektedir. Bununla birlikte sapkın sürücü davranışları arasında katılımcıların saldırgan ihlaller öz bildirim sıklığının diğer tüm davranış tiplerinden daha yüksek olduğu görülmüştür. KPE-D bulguları incelendiğinde, tüm alt ölçeklerin, KPE-D'nin ortalama puanlarına göre katılımcılar tarafından benzer sıklıkta değerlendirildiği görülmektedir. Bununla birlikte, KPE-D'nin arkadaşça oktantı diğer yedi oktantla karşılaştırıldığında en yüksek; baskın oktantı ise aynı karşılaştırmada en düşük puan almış oktantlar olarak ortaya çıkmıştır (Bkz. Tablo 3).

KDM alanındaki yerleşime göre, saldırgan ihlaller ve sıradan ihlaller, döngünün "düşük yakınlık-yüksek baskınlık" çeyreğinde temsil edilmiştir. Hatalar "düşük yakınlık-düşük baskınlık”" çeyreğinde; ancak "düşük baskınlık” vektörüne oldukça yakın bir konumda temsil edilmiştir.

Ayrıca, ihmal ve dalgınlıklar "düşük yakınlık" vektörüne yakın olsa da neredeyse döngünün merkezinde temsil edilmiştir. Son olarak, pozitif sürücü davranışlarının döngünün "yüksek yakınlıkdüşük baskınlık" çeyreğinde temsil edildiği görülmektedir (Bkz. Şekil 2).

\section{Tartışma}

$\mathrm{Bu}$ çalışmanın temel amacı trafikteki sürücü davranışlarının Kişiler Arası Döngüsel Model (KDM) üzerindeki temsillerini incelemektir. Sürücü davranışları bugüne kadar risk alma, heyecan arama, nevrotiklik gibi farklı kişilik özellikleri ile ilişkilendirilmiştir (Bkz. Oltedal ve Rundmo, 2006; Rimmö ve Aberg, 1999; Dahlen ve White, 2006; Reimer ve ark., 2005); ancak bu araştırmaların hiçbiri sürücü davranışlarının kişiler arası problemlerle ve davranışlarla ilişkisini çalışmamıştır. Bu inceleme literatürde ilk defa bu çalışma kapsamında yapılmaktadır. 
Tablo 3. Araştırma Değişkenlerinin Tanımlayıcı İstatistikleri

\begin{tabular}{lccccc}
\hline Deği̧̧kenler & $\mathrm{N}$ & Ortalama & $\begin{array}{c}\text { Standart } \\
\text { Sapma }\end{array}$ & Min & Maks \\
\hline İhmallerve & 355 & 1.61 & .41 & 1.00 & 3.13 \\
$\begin{array}{l}\text { Dalgınlıklar } \\
\text { Hatalar }\end{array}$ & 355 & 1.58 & .44 & 1.00 & 3.50 \\
$\begin{array}{l}\text { Saldırgan } \\
\text { Ihlaller }\end{array}$ & 355 & 2.05 & .79 & 1.00 & 5.67 \\
$\begin{array}{l}\text { Siradan } \\
\text { Ihlaller }\end{array}$ & 355 & 1.81 & .60 & 1.00 & 4.56 \\
$\begin{array}{l}\text { Pozitif } \\
\text { Sürücü }\end{array}$ & 355 & 4.58 & 1.00 & 1.11 & 6.00 \\
Davranı̧̧lan & & & & & \\
Baskın & 355 & 1.95 & .71 & 1.00 & 4.75 \\
$\begin{array}{l}\text { Düşmanca- } \\
\text { Baskın }\end{array}$ & 355 & 1.99 & .74 & 1.00 & 4.25 \\
$\begin{array}{l}\text { Düşmanca } \\
\text { Dü̧̧manca- }\end{array}$ & 355 & 2.01 & .77 & 1.00 & 4.25 \\
Itaatkâr & 355 & 1.99 & .82 & 1.00 & 5.00 \\
Itaatkâr & 355 & 2.33 & .78 & 1.00 & 4.50 \\
$\begin{array}{l}\text { Arkadaşça- } \\
\text { Itaatkâr }\end{array}$ & 355 & 2.37 & .73 & 1.00 & 5.00 \\
$\begin{array}{l}\text { Arkadaşça } \\
\text { Arkadaşça- }\end{array}$ & 355 & 2.72 & .85 & 1.00 & 5.00 \\
Baskın & 355 & 2.39 & .74 & 1.00 & 5.00 \\
\hline
\end{tabular}

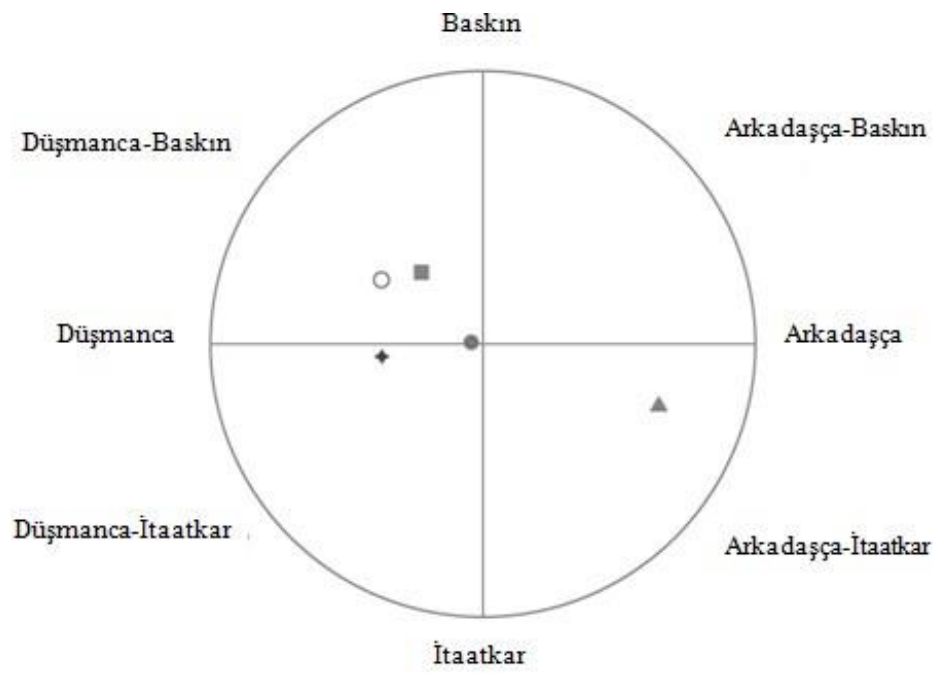

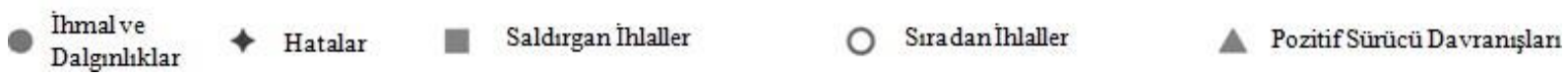

Şekil 2. Sürücü Davranışlarının Kişiler Arası Döngüsel Model Üzerindeki Temsilleri 
Trafik ortamı bir kişiler arası ilişkiler ortamıdır. İnsanların araç kullanırken de diğer sürücüler ve yol kullanıcıları ile etkileşim içinde olduğu, kişiler arası davranışların sergilendiği, sorunların oluştuğu bu ortamda sürücülükte insan faktörlerini anlamlandırmak ve sürücülük davranışlarının hangi bireysel ve çevresel faktörlerle ilişki içinde olduğunu bulmak anlamlı değere sahiptir. KDM'ler bu bilgiyi sağlayabilecek, alan yazında daha önce farklı bağlamlarda çalışılmış, geçerli ve güvenilir sonuçlar vermiş modellerdir. Örneğin, kişilik bozuklukları (Alden ve Capreol, 1993; Stern, Kim, Trull, Scarpa ve Pilkonis, 2000; Lejuez ve ark., 2003) ve klinik terapötik kullanımlar (Muran, Segal, Samstag ve Crawford, 1994; Borkovec, Newman, Pincus ve Lytle, 2002; Hansen ve Lambert, 1996) bu modeller temelinde incelenmiştir. Bu çalışma kapsamında kullanılan KDM de trafik bağlamında davranış dağılımının incelenmesiyle anlamlı sonuçlar sunmuştur.

SDÖ alt ölçeklerinin bu çalışmadaki sonuçlarına göre, sürücüler kendilerini sapkın sürücü davranışlarına göre pozitif sürücü davranışlarına daha fazla meyilli olarak değerlendirmişlerdir. $\mathrm{Bu}$ bulgu sürücülerin genel eğilimlerinin, sapkın davranışlarda bulunmaları ile ilgili öz bildirimlerinin düşük, pozitif davranış öz bildirimlerinin yüksek olması yönünde olduğunu gösteren farklı sürücü gruplarından elde edilmiş önceki çalışma bulgularıyla uyum içindedir (örneğin, Öz, Özkan ve Lajunen, 2014; Özkan ve Lajunen, 2005). Çalışmaya katılan sürücülerin KPE alt ölçeklerindeki sonuçlara göre, sürücüler baskınlık ve yakınlık koordinatlarından oluşan dairesel düzlemin yüksek yakınlık çeyreklerine ait olduklarını belirtmişlerdir. Bir başka deyişle, çalışmaya katılan sürücüler bu düzlemin itaatkar, arkadaşça-itaatkar, arkadaşça ve arkadaşça- baskın kısımlarına yoğun bir şekilde dağılım göstermişlerdir.

Sürücü davranışlarının kişiler arası döngüsel model üzerindeki temsilleri incelendiğinde; başkalarının bakış açılarını görememe, başkaları ile tartışmaya girme eğiliminde olma, öfke ve sinirlilik ifadesi ve deneyimine sahip olma, başkalarına güvenmeme, diğer insanların ihtiyaçlarını göz ardı etme, sorumsuz olma, asgari düzeyde sevgi ve bağlanma gösterme, başka insanlara sempati, bakım, sıcaklık ve cömertlik göstermeme gibi kişiler arası problemlere sahip olan sürücülerin, trafikte daha çok saldırgan ve sıradan ihlal yapan sürücüler olduğu görülmektedir.

Reason ve arkadaşlarının (1990) ihlal tanımına bakıldığı zaman, sıradan ihlallerin temelde trafikte kural ihlali içerikli, saldırgan ihlallerin ise diğer yol kullanıcılarını zor durumda bırakacak niyetli sapkın davranışlar olduğu görülmektedir. Bu tür davranışların da bu çalışmada ihlalle ilişkili olduğu belirtilen ve yukarıda sıralanan kişilerarası özelliklerle birlikte gruplanması beklendik bir bulgudur. SDÖ kapsamında yapılmış olan ihlal tanımlaması ve incelemesinin yanında, bu çalışmanın bulgularını destekleyen bir başka açıklama da Mesken, Lajunen ve Summala (2002) tarafindan sunulmuştur; araştırmacılar kişiler arası ihlal kavramından bahsetmişlerdir. Kişiler arası ihlaller, sürücülerin diğer yol kullanıcılarının haklarına saygı göstermemesi ve başkalarına fiziksel veya psikolojik zarar verme potansiyeline sahip olmasını içerir. Bu tanımlama da bu çalışmada elde edilen kişiler arası problemler ve sürücü ihlal davranışları ilişkisinin varlığını destekler niteliktedir.

Çalışmanın diğer bir bulgusu, diğer insanlara karşı sempati, hoşnutluk, sıcaklık ve cömertlik hissetmeyen, onlarla birlikteyken endişeli, çekingen ve utangaç olan, sosyal etkileşimlere başlayamayan, kendine güven ve benlik saygısı düşüklüğü yaşayan, inisiyatif alamayan, sosyal olarak zorlayıcı durumlardan kaçınan sürücülerin trafikte daha çok hata yaptıklarıdır. Bir sürücü davranışı olarak hatanın tanımına bakıldığında bu davranışların aslında niyet içermeyen, planların 
yanlış yapılması veya yanlış uygulanması sonucunda yaşanan davranışlar olduğunu görmekteyiz. Trafikte hata yapmanın döngüsel modelde yukarıda bahsedilen KPE-D problemlerinin bulunduğu alanda gözlemlenmesi yine niyetli davranışlar olmasa da sapkın bir davranış olan hataların bu tip kişiler arası problemlerle ilişkili olduğunu göstermiştir. Başka bir deyişle niyetli yapılmasa da sapkın davranışlar ve kişiler arası problemler yine bir arada gözlemlenmiştir. Bu ilişkinin açıklayıcı bir anlam ifade edip etmediği, daha detaylı ve risk almak, heyecan aramak, zihinsel yük, stres seviyesi ve benzeri başka karıştırıcı bireysel değişkenlerin de bulunacağı sonraki çalışmalarca incelenmelidir.

Bunun yanında, inisiyatif alamama, sosyal açıdan zorlayıcı durumlardan kaçınma, başkalarına 'hayır' diyememe, öfke hissi ve ifadesinin zayıf olması, kolay ikna olma ve kolay aldatılma, fazla istekli olma, kendine güven ve benlik saygısının ciddi derecede düşük olması, çok cömert, çok bakım veren, çok güvenen, çok izin veren bir kişi olma ve ilişkilerde sınırları korumakta zorlanma gibi problemlere sahip olan kişilerin trafikte pozitif sürücü davranışlarını sıklıkla sergiledikleri görülmektedir. Pozitif sürücü davranışları trafik güvenliği ana amacıyla yapılan davranışlar değildir. Diğer yol kullanıcılarını ve trafik ortamını koruyup kollamaya odaklanan davranışlardır. Pozitif davranışların bu içeriğine bakıldığında, kişiler arası ilişkilerde fazla güvenme ve bakım verme gibi problemlerin bu davranışların modelde yer aldığı düzlemde görülmesi beklendik bir bulgudur; bahsedilen davranışlarla yine bahsedilen problemlerin içerikleri böyle bir etkileşimi beklenir yapmaktadır. Bununla birlikte, düşük özgüven, benlik saygısının düşük olması gibi bazı problemlerin de pozitif sürücü davranışlarıyla birlikte görülmesi, belki kişilerin kendilerini yeterli hissetmedikleri durumlarda içinde bulundukları ortamlarda pozitif davranışlar sergileyerek daha iyi hissetme, kendilerini diğer insanların gözünde daha iyi bir yere yerleştirme çabasının sonucu da olabilir. $\mathrm{Bu}$ davranış-kişiler arası problem dağılımının detaylı sebepleri için bu fikirleri test edecek gelecek çalışmalar gerekmektedir.

Son olarak 'ihmal ve dalgınlıklar' davranışlarının KDM'nin merkezi noktasına yakın temsil edilmesi dikkat çekicidir. Bu konumun herhangi bir çeyreğin belirgin özelliklerine sahip olmadığı söylenebilir. Bu sebeple, ihmal ve dalgınlıkların bu çalışmadaki konumlanmasının, bu sapkın sürücü davranışlarının döngüdeki temel problemlerin hiçbirini tam olarak yansıtmadığı gösterdiği söylenebilir. Bu sonuç, ihmal ve dalgınlıkların hafıza ve dikkat bozuklukları temelli ortaya çıktığı düşünüldügünde beklendik bir sonuçtur. Kişinin ihmal ve dalgınlık davranışlarının kendi içinde olumsuz veya olumlu niyetinden, yaptığı planın uygulanma veya süreç hatalarından kaynaklanan bir sebepten değil, zihinsel süreçlerin aksamasından, bir başka deyişle bazı "teknik" sebeplerden kaynaklanması, herhangi bir kişiler arası problemle ilişkili olmaması bu davranışların tanımına bakıldığında anlamlı ve tahmin edilir bir bulgudur.

Bu çalışma, daha önceki uygulamalarında özellikle klinik ortamlarda çalışılmış olan kişiler arası problemler değişkeninin başka bir uygulama alanı olan trafik ortamında çalışılmasına olanak vermiştir. Bu durum KDM ve KPE-D ölçeğinin kullanımı ve test edilmesi için değişik bir ortam sunmuştur; sürücü davranışları literatüründe de davranışla ilişkili faktörlere bir yenisinin daha eklenmesini sağlamıştır. Uygulama açısından bakıldığında, çalışmanın sonuçları trafikte sapkın davranışlar olan ihlal veya hata eğilimli sürücülere yönelik müdahale programlarının hazırlanmasında, kişiler arası problem tiplerinin dikkate alınmasının anlamlı olabileceğini göstermiştir.

Teorik olarak ve uygulamada alan yazına katkı potansiyeli yüksek olan bu çalışmanın bazı 
sınırlılıkları da bulunmaktadır. Veri toplama yöntemi öz bildirime dayandığı için bu çalışma kapsamında elde edilmiş bazı cevaplar yanlı olabilir, katılımcılar toplumsal olarak istenen cevapları vermiş olabilir. Bu çalışmanın verilerinin analiz edilme yöntemi ve çalışmanın kesitsel niteliği, sebepsonuç ilişkileri çıkarmayı mümkün kılmamıştır.

$\mathrm{Bu}$ çalışma, sürücü davranışları ile KDM yapıları arasındaki ilişkiyi araştıran ilk çalışmadır. Sürücülük sadece bir aracı bir noktadan diğerine götürmeyi değil aynı zamanda bu temel görevi yerine getirirken hem güvenlik odaklı olmayı hem de trafikte araç dışı faktörlerin etkisine maruz kalıp bu etkiyi dengelemeyi gerektirmektedir. Kişilerin herhangi bir bağlam özelinde görülmeyen, genel hayat ortamlarında gözlemlenebilen çeşitli özellik ve problemleri de kendilerini belli bağlamlarda farklı davranışlarla yansıtabilir. Bu davranışlar trafik ortamında hem sapkın, hem pozitif sürücü davranışlarıdır. Sürücüler trafikte diğer yol kullanıcıları ile davranışları yoluyla iletişim kurmaktadırlar ve bu davranışlar kişiler arası ilişkilerinden ve problemlerden etkilenmektedir. $\mathrm{Bu}$ nedenle kişiler arası etkileşimler ve sürücü davranışları arasındaki ilişkiyi araştırmak önemlidir. Bu çalışma trafik ortamlarındaki kişiler arası problemleri inceleyecek gelecekteki çalışmalara temel hazırlayan bir referans çalışma olmuştur. Gelecek çalışmalarda bu çalışmanın tanımlayıcı bulgularının açıklayıcı yöntemlerle daha detaylı anlamlandırılması hem sürücülükte insan faktörlerinin hem de kişiler arası problemlerin daha ayrıntılı anlaşılması için gerekli ve faydalı görünmektedir.

Bilgilendirme: Bu makale yazar Özge Özer'in yazar Bahar Öz danışmanlı̆̆ında tamamladığı “An Investigation of Driver Behaviors: Their Relationship with Interpersonal Problems and Representations on the Interpersonal Circumplex" başlıklı yüksek lisans tez çalışmasından üretilmiştir. 


\section{Kaynakça}

Akyunus, M. (2012). Cognitive Aspects of Personality Disorders: Influences of Basic Personality Traits, Cognitive Emotion Regulation, and Interpersonal Problems (Doctoral dissertation). Middle East Technical University.

Akyunus, M., \& Gençöz, T. (2016). Kişilerarası Problemler Envanteri-Döngüsel Ölçekler Kısa Formu psikometrik özellikleri: Güvenilirlik ve geçerlik çalışması. Düşünen Adam: Psikiyatri ve Nörolojik Bilimler Dergisi, 29(1), 36-48.

Akyunus, M., \& Gençöz, T. (2016). Kişilik Bozukluğu İnanışlarının Kişilerarası Döngüsel Model Üzerindeki Temsili. Türk Psikoloji Dergisi, 31(77), 1.

Alden, L. E., \& Capreol, M. J. (1993). Avoidant personality disorder: Interpersonal problems as predictors of treatment response. Behavior Therapy, 24(3), 357-376. doi:10.1016/s00057894(05)80211-4

Alden, L. E., Wiggins, J. S., \& Pincus, A. L. (1990). Construction of circumplex scales for the Inventory of Interpersonal Problems. Journal of Personality Assessment, 55(3-4), 521-536.

Borkovec, T.D., Newman, M.G., Pincus, A. L., \& Lytle, R. (2002). A component analysis of cognitive-behavioral therapy for generalized anxiety disorder and the role of interpersonal problems. Journal of Consulting and Clinical Psychology, 70(2), 288-98.

Çabuk, O. C. (2015). The Roles of Childhood Trauma, Personality Characteristics, and Interpersonal Problems on Psychological Well-Being (Master's Thesis). Middle East Technical University.

Dahlen, E. R., \& White, R. P. (2006). The Big Five factors, sensation seeking, and driving anger in the prediction of unsafe driving. Personality and Individual Differences, 41(5), 903-915.

Elander, J., West, R., \& French, D. (1993). Behavioral correlates of individual differences in roadtraffic crash risk: An examination of methods and findings. Psychological Bulletin, 113(2), 279.

Foa, U. G. (1961). Convergences in the analysis of the structure of interpersonal behavior. Psychological Review, 68(5), 341.

Forgas, J. P. (2002). Feeling and doing: Affective influences on interpersonal behavior. Psychological Inquiry, 13(1), 1-28.

Gurtman, M. B., \& Pincus, A. L. (2003). The Circumplex Model: Methods and Research Applications. Handbook of Psychology. doi:10.1002/0471264385.wei0216

Hansen, N. B., \& Lambert, M. J. (1996). Brief report: Assessing clinical significance using the Inventory of Interpersonal Problems. Assessment, 3(2), 133-136.

Horowitz, L. M., Alden, L. E., Wiggins, J. S., \& Pincus, A. L. (2003). Inventory of Interpersonal Problems Manual. The Psychological Corporation: Texas.

Horowitz, L. M., Rosenberg, S. E., Baer, B. A., Ureño, G., \& Villaseñor, V. S. (1988). Inventory of interpersonal problems: psychometric properties and clinical applications. Journal of Consulting and Clinical psychology, 56(6), 885.

Horowitz, L. M., Wilson, K. R., Turan, B., Zolotsev, P., Constantino, M. J., \& Henderson, L. (2006). How interpersonal motives clarify the meaning of interpersonal behavior: A revised circumplex model. Personality and Social Psychology Review, 10(1), 67-86.

Jones, E. E. (1986). Interpreting interpersonal behavior: The effects of expectancies. Science, 234, 
41-47.

Lajunen, T., Sümer, N., \& Özkan, T. (2003). The Turkish Driver Behavior Questionnaire (TDBQ): validity and norms. Unpublished manuscript.

Lawton, R., Parker, D., Manstead, A. S. R., \& Stradling, S. G. (1997). The role of affect in predicting social behaviors: the case of road traffic violations. Journal of Applied Social Psychology, 27, 1258-1276.

Lejuez, C. W., Daughters, S. B., Nowak, J. A., Lynch, T., Rosenthal, M. Z., \& Kosson, D. (2003). Examining the inventory of interpersonal problems as a tool for conducting analogue studies of mechanisms underlying borderline personality disorder. Journal of Behavior Therapy and Experimental Psychiatry, 34(3), 313-324.

Locke, K. D. (2010). Circumplex Measures of Interpersonal Constructs. Handbook of interpersonal psychology: Theory, research, assessment, and therapeutic interventions, 313.

Mesken, J., Lajunen, T., \& Summala, H. (2002). Interpersonal violations, speeding violations and their relation to accident involvement in Finland. Ergonomics, 45(7), 469-483.

Muran, J. C., Segal, Z. V., Samstag, L. W., \& Crawford, C. E. (1994). Patient pretreatment interpersonal problems and therapeutic alliance in short-term cognitive therapy. Journal of Consulting and Clinical Psychology, 62(1), 185-190. doi:10.1037//0022-006x.62.1.185

Oltedal, S., \& Rundmo, T. (2006). The effects of personality and gender on risky driving behaviour and accident involvement. Safety science, 44(7), 621-628.

Öz, B., Özkan, T., \& Lajunen, T. (2014). Trip-focused organizational safety climate: investigating the relationships with errors, violations and positive driver behaviours in professional driving. Transportation Research Part F: Traffic Psychology and Behaviour, 26, 361-369.

Özkan, T. (2006). The regional differences between countries in traffic safety: a cross-cultural study and Turkish case. University of Helsinki, Helsinki, Finland. (http://ethesis.helsinki.fi/julkaisut/kay/psyko/vk/ozkan/theregio.pdf).

Özkan, T., \& Lajunen, T. (2005). A new addition to DBQ: Positive Driver Behaviours Scale. Transportation Research Part F, 8, 355-368.

Pincus, A. L., \& Ansell, E. B. (2003). Interpersonal Theory of Personality. Handbook of Psychology. doi:10.1002/0471264385.wei0509

Reason, J., Manstead, A., Stradling, S., Baxter, J., \& Campbell, K. (1990). Errors and violations on the roads: a real distinction?. Ergonomics, 33(10-11), 1315-1332.

Reimer, B., D’Ambrosio, L. A., Gilbert, J., Coughlin, J. F., Biederman, J., Surman, C., ... \& Aleardi, M. (2005). Behavior differences in drivers with attention deficit hyperactivity disorder: The driving behavior questionnaire. Accident Analysis and Prevention, 37(6), 9961004.

Rimmö, P. A., \& Åberg, L. (1999). On the distinction between violations and errors: sensation seeking associations. Transportation Research Part F: Traffic Psychology and Behaviour, 2(3), 151-166.

Road traffic injuries. (WHO). Retrieved January 14, 2018, from http://who.int/violence_injury_prevention/road_traffic/en/

Stern, B. L., Kim, Y., Trull, T. J., Scarpa, A., \& Pilkonis, P. (2000). Inventory of Interpersonal Problems Personality Disorder Scales: Operating Characteristics and Confirmatory Factor 
Analysis in Nonclinical Samples. Journal of Personality Assessment, 74(3), 459-471. doi:10.1207/s15327752jpa7403_9

Wallén Warner, H. (2006). Factors Influencing Drivers' Speeding Behaviour (Doctoral dissertation, Acta Universitatis Upsaliensis).

Wiggins, J. S., \& Pincus, A. L. (1989). Conceptions of personality disorders and dimensions of personality. Psychological Assessment: A Journal of Consulting and Clinical Psychology, 1(4), 305.

(n.d.). Retrieved January 14, 2018, from http://www.trafik.gov.tr/Sayfalar/Istatistikler/GenelKaza.aspx 


\title{
Summary
}

\section{Representations of Driver Behaviors on the Interpersonal Circumplex Model}

\author{
Özge Özer, M. A. \\ Bahar Öz, Asst. Prof. \\ Middle East Technical University \\ Faculty of Arts \& Sciences, Department of Psychology
}

Although driver behaviors were studied in relation to different individual related factors, interpersonal problems are not one of those factors. This seems to be a critical point as traffic environment is a social context in which drivers interact with other road users and reflect their interpersonal problems in their behaviors. In the previous studies, different ways and strategies have been used to investigate interpersonal problems but interpersonal circumplex model offered a balance of comprehensiveness and simplicity, and it helped to build a multidimensional understanding of the interpersonal world. Moreover, in the literature, human factors in driving (i.e., driver behaviors and driving skills) were studied through different models and methods.

However, the distinction between errors, slips and lapses, aggressive and ordinary violations as different types of aberrant driver behaviors had critical impact in driver behavior research. Errors can be defined as "the failure of planned actions to achieve their intended consequences" and slips and lapses as "attention and memory failures". As different from errors and slips and lapses, violations can be defined as "deliberate deviations from those practices believed necessary to maintain the safe operation of a potentially hazardous system". On the other hand, there were some other behaviors than aberrant behaviors in everyday driving. The most important motivation in those behaviors was being careful about the traffic environment or other road users and to help and be polite with or without safety concerns. Those kinds of behaviors could be named as "positive driver behaviors". The aim of the current study was to investigate the relationship between driver behaviors and interpersonal problems and detect the positions of driver behaviors on interpersonal circumplex (IPC). A total of 355 drivers (109 females, 246 male) from different regions of Turkey participated in this study. They were given The Driver Behavior Questionnaire and the Positive Driver Behaviors to Scale to measure aberrant and positive driver behaviors, respectively. They were also asked to complete the Inventory of Interpersonal Problems which was developed based on the IPC and measuring individuals' problematic or challenging experiences in their interpersonal relationship. Ipsatized data method was used for examining the relationship between study variables and detecting the positions of drivers on the IPC. According to the placement on the IPC space, Aggressive Violations and Ordinary Violations were represented on the 'low affiliation-high dominance' quadrant of the circumplex. Moreover, Errors were represented on the 'low affiliation-low dominance' quadrant but close to the 'low affiliation' vector of the circumplex. Besides, Slips and Lapses were placed very close to 'low affiliation' vector and the center of the circumplex. Finally, Positive Driver Behaviors were represented on the 'high affiliation-low dominance' quadrant of the circumplex. Results showed that the representation of the driver behaviors-interpersonal problems relationship on the IPC is observed in accordance with the content and definitions of those two concepts. This study was the first to examine and plot the representations of driver behaviors on the IPC space and integrate those two 
concepts. Also, to our knowledge this study is the first one to investigate the relationship between driver behaviors and IPC structures. Evidencing the interpersonal problems and aberrant/positive driver behaviors relationship was a theoretical contribution to the literature investigating personality and interpersonal relationships at traffic context. From the practical point of view, the results showed that in preparing intervention programs for the violation and/or error prone drivers, their interpersonal problem types could be considered. The results and implications of the study were evaluated and discussed in detail. 